\title{
Liberal Feminism In Movie North Country Directed By Niki Caro
}

\author{
Dwi Puji Hastuti ${ }^{1}$, Deni Gunawan ${ }^{2}$, Ria Andriani ${ }^{3}$ \\ ${ }^{1}$ Akademi Bahasa Asing \\ email : dwi.dsu@bsi.ac.id \\ ${ }^{2}$ Akademi Manajemen Informatika \\ email : deni.dee@bsi.ac.id \\ ${ }^{3}$ Akademi Sekertari dan Manajemen \\ email : $\underline{\text { ria.rii@bsi.ac.id }}$
}

\section{Cara Sitasi:}

Hastuti, D. P., Gunawan, D., \& Andriani, R. (2018). Liberal Feminism In Movie North Country Directed by Niki Caro. Wanastra2, 10(2), 91-104.

\begin{abstract}
Women is still in lower position in every chace, especially in workplace. Equal rights is a must where every individual can get it. The purpose of this paper are explore about problems which happend there such as the reason why it can happend, impacts that main character and her co-worker as long as they work, and also obstacles in fighting for women's right. This research uses descriptive qualitative method, data analysis is described by using words. Source date is taken from books and online resources, and others resource which completed this paper. This reasearch want to discuss about liberal feminism in this film, it is one of branch feminism theory which focused on fight for women's right. As the result, Josey as the main character, she is bravely and clear woman who able speak out freedom for women and equal rights in workplace although almost the most worker there are men. Finally, with hard struggle and feel give up, she can do it.
\end{abstract}

Keywords : Liberal, Feminism, Liberal Feminism.

\section{INTRODUCTION}

Discourse about women never stops and always studied, this is evidenced by history. It always discussed on many occasions, both discussions and seminars. The discussion above covers all aspects of women's lives including the female reproductive organs, position in the family, community, and workplace. Human have been born with two gender, men and women. Women can not choose which one both of those are better for her. Characters of men are strong, masculine; think with their logic, dominant whereas characters of women are soft, feminism, think with their heart also comparison which one is better or contrary and defeatism. These are kinds of traditional perception or patriarchy culture. Some of women in this era disagree about this thought. Equality in every aspects have been a must to break out of old traditions that women is only being a housewife who always do household such as cook, wash clothes, sweep floor, take care of husband and children's, etc.
Women has rights to do something more than she always do in their daily life. Women can do everything as long as she can do, and she is also looks strong inside and outside. There are many significant improvements when women can fulfill in all aspects such as being president, minister, director, etc. But not all women nowadays can feel so, there are many women outside still follow their traditional rules because their parents or neighborhoods believe it is women's nature. Many women still feels discriminations.

The discriminations can be happen whenever and wherever because of there are not rights equality between women and men which happened in family, environment, and fieldwork. In family, these are often happen because women only being housewife or may be housemaid who always do in culinary (cooking, washing plates, and tidy something), in bed (do husband desire), and bathroom (washing clothes). In environment, perspectives about women are low reactions and does not need get high education. Whereas in fieldwork, performance of women in work reputed unimportant, perception of woman are not as strong 
as man who are always defends faces all troubles, and also women always unprofessionally.

In fieldwork, performance of women reputed such as unimportant person because of she is slowmoving, not handy, and unable in her field. For example, a women who work as security women in factory, many society perceptions usually only men who can do that. Sometimes normal person can not accept it.

Whereas perceptions women are not as strong as man, it also contrast with opinion "do like a man" these perceptions are always say all authority person when there is a women work in their company. For example a women who work in back country as a teacher in those places in Indonesia. She must faced all the conditions where are not anything else and being isolated such as clothing, food, and housing. It is not easy to face it and sometimes she will choose go back to their home. Women always unprofessionally, these are one of classic problem where most people agree with it. Women always do with feeling than logic. So, if there is problem, men always predict women will unprofessionally. Actually women are live creature from God who can be strong outside and inside. For example, a women employee does her job to make finance report suddenly she reminds that she has family problems. Although it just simple problem, it could be big problems someday.

In this case, the writer will focus in Josey Aimes's character as the object of the research. Josey Aimes, who is a collier woman works at the local iron mines in Northern Minnesota, Minneapolis, New Mexico. North Country Movie is a movie that mainly talks about liberal feminism by the main character. It was inspired by the 2002 book Class Action: The Story of Lois Jenson and Landmark Case That Changed Sexual Harassment Law by Clara Bingham and Laura Leedy Gansler, which chronicled the case of Lois Jenson and other female workers at the Eveleth Taconite Co. Josey Aimes and the other female workers become the target of sexual harassments and discriminations. That is why she, Josey Aimes, wants to fight for the women rights workers who worked in the mines by make little rebellions until she sued the company which have alleging sexual harassment, discrimination and lack of mutual respect towards one and another worker. This is what writer want to discuss, about movement of main character who fights for women rights it can be symbolized or representation of being feminist. The benefits of understanding this film are how can faced faith if women have born being women who have many problems in life and also getting equal rights wherever she is because women nowadays still have discriminations.
Women must be strong to face how hard her life. Encourange knowledge about perspective feminism in movie.

\section{THEORETICAL FRAMEWORK}

\section{Definition of Feminism}

Feminism describes a culture which women are treated differently than men. Difference of treatment women are disadvantage, feminism assumes that such treatment is cultural and thus possible to change and not simply "the way world is and must be". Feminism looks different culture as possible and values moving towards that culture. Feminism also consists of activism, individually and in groups, to make personal and social change towards that more desirable culture.

It has been proof by feminism. It has been surrounding in society nowadays because of their movements to changes, support, give freedom for women to do what she wants. Feminism has spread all over the world and has been literature and growing very widely. Feminism has gradually become more far-ranging and subtle in its attacks on male-dominated society. Many injustices still need to be corrected but equally necessary is a more down-to-earth, tolerant and compassionate view of fellow human beings. The gathering feminist movement very much disagreed and argued that women's writing expressed a distinctive female conciousness, which was more discursive and conjuctive than its male counterpart.

Different theories of feminism are widely acknowledged and taught in women's studies courses, gender studies courses, and etc. People often have created their own definition of feminism to best suit them. The definitions here are theoretical, and are an example of the diversity among feminists. Why women believes in feminism and what her ideas are to make feminism a reality is the primary source of conflict within the feminism movement. Women may find that she believe in the theory of feminism, but do not see ourself fitting into the branches of feminism below, that is common. Women can believe that women and men should be politically, economically and socially equal for her own reasons and hold ideas touching how she can make that happen. The case likely practicing some form of feminism whether or not you directly associate yourself with the feminist movement or theory.

Butler (1999 : 1) said that "feminist theory has assumed that three is some existing identity, understood through the category of women, who not 
only initiates feminist interests and goals within discourse, but constitutes that subject for whom political representation is persued." It means that feminism exists because of some reasons that women is one of important part in human life.

Hook (2000 : viii) statement "Feminism is a movement to end sexism, sexist exploitation, and oppression." Meaning of the statement is women wants being appreciated and also have value in human society without exploitation and oppression.

Beasly from Women and Moral Identity 1991 (1999 : 27), "I adopt a general definition of feminism as a perpective that seeks to eliminate the subordination, oppression, inequalities and injustices women suffer because of their sex." It means some people think that women has become object of negative behaviour.

Beasly from Encyclopedia of Feminism, 1987 (1999 : 27) :

"[Feminism] is the advocacy of women's rights based on a belief in the equality of the sexes, and in its broadest use the word refers to everyone who is aware of and seeking to end women's subordination in any way and for any reason...Feminism originates in the perception that there is something wrong with society's treatment of women.

Those statements have meaning that feminism is theory that men and women should be equal politically, economically and socially.

From the three statement above, definition of feminism is very large but has the same point, equality in every aspect for women. If it can happen, it can changed people's opinions that women in this era is modern and not patriarcy anymore.

The writer concludes that definition of feminism itself is a theory that fighting for women's rights and also against patriarchy which discrimination of women.

\section{Kinds of Feminism}

Based on Beasley (1999 : 51 - 63) in her book entitled "What is Feminism ?" there are 4 branches of feminism :

a. Liberal Feminism is women's position in society is seen in terms of enequal rights or artificial' barriers to women's participation in the public world, beyond the family and household. It focus on the public sphere, legal, political, and institutional struggles for the rights of individuals to complete in public.

b. Radical Feminism is sexual oppression as the or at the very least a fundamental form of oppression (usually the former) and the primary oppression for women. In radical feminism all men as a group are unambiguously viewed as having power over at least some wome.

c. Marxist Feminism is oriented towards the public sphere and given its concern with the organisation of labour, generally pays particular attention to women's position in relation to waged labour.

d. Socialist Feminism is attempt to mantain some elements of Marxism regarding the significance of class distinctions and labour while incorporating the radical feminist view that sexual oppression is not historically a consequence of class division.

In this occassion, the paper only discuss about liberal feminism which concern equality of women's position in society, enviroment, and also workplace.

\section{Definition of Liberal}

Everyhuman being has freedomof every individual. Liberals and freedom is a thing that can not be separated from one another. Liberals can be interpreted as a freedom to choose, make, and make choices that there are no obstacles. For the past few Liberal theories suggested by experts is one of the best ways to free people choose wherever people want. It is because of mistrustin the ability of the individual fairly curbed partly due to different of the other race, religion, gender and sex. With the advent of liberal theory makes some people feel good because they can be recognized freedoms and make them able to carry out the purposeof life that they want without certain limitations.

Tong (2009 : 11), "Liberals define reason largely in moral or prudential terms, they nevertheless concur that a just society allows individuals to exercise their autonomy and to fulfill themselves. Liberals claim that the "right" must be given priority over the "good"." It means that liberal must give rights for every human and it should be the most important things to reminds that every human has individuals rights.

Jaggar (1983:6), "Liberation is the correlate of oppression. It is release from oppressive constraints." It means that one of the reason appeared liberal is because of there are oppression 
which happen in women and man eventhough in the other side.

\section{Schwartzman (1969: 1) :}

"Liberal concepts can work to undermine women's interests, reinforcing not only sexism, but also racism, classism, and other forms of oppression... "right to privacy" to argue that the state should not interfere in situations of domestic violence and marital rape, as well as more recent cases in which racist hate speech, violent pornography, and sexually harassing speech have been granted protection under the right to "freedom of expression".

It means that freedom of expressions means that everything can be changed when we have freedom, rights to privacy means that everybody has rights to do individually that no one know or no one to join it.

Based on three statement above, liberal have many definitions but actually liberal can work in every aspect because every human have rights to do something, get freedom of expression. Although from Jaggar said that it correlate of oppression because many people get some disturbance in past such as people who against goverment will be execution like Soeharto goverment. There are not liberal to give critical or opinin for goverment.

Definition of Liberal is a theory that given freedom for many people to choose and get the best from many choices in the world, give critical or opinition about something and take an action to do something in many aspects as long as still in normal way not break over society rules.

\section{Definition of Liberal Feminism}

Women emancipations have existed to erase different of gender. Feminism is a ideology which use to break out patriarchy, search for the root or causes of discrimination of women and also look for the solutions. In other words, feminism is a theory for women liberation.

Ideologi of liberal feminism is equality in every chance and desire in order to every individual (men and women) have given freedom to choose what goodness the way she or he did without harm others. The prior purpose are make the society feel equitable and care of freedom places to make an improvement. Only from those environments, women and men can develop their self.

General view of the liberal feminists is that suppress of women is caused by social and legal barriers that block their access to public sphere of politics and economics. Liberal feminists demand that liberals follow their own principles of universal human rights and equality and demand equal treatment of women and men, insisting that women are fundamentally similar to men. These theorists argue for law to be gender blind- that there should be no restrictions or special assistance on the grounds of gender.

Emphasizing equal individual rights and liberties for women and men, downplaying sexual differences. Liberal feminism is the most widely accepted social and political philosophy among feminists. Liberal feminists defend the equal rationality of the sexes and emphasize the importance of structuring social, familial, and sexual roles in ways that promote women's autonomous self-fulfillment. They emphasize the similarities between men and women rather than the average differences between them, attribute most of the personality and character differences between th sexes to the social construction of gender, and tend to promote a single set of androgynous virtues for both women and men.

So, feminism liberal is one of branch feminism which is presented of equal rights for women can be accepted legally and also get improvement in social aspect in order to every women rights can be realization if women can be equal with men.

Beasley (1999:51), “[Liberal Feminism] is women's position in society is seen in terms of unequal rights or 'artificial' barriers to women's participation in the public world, beyond the family and household." It means positions of women in that moments, there are many unequal rights beyond women and men. Discrimination always happen and it could not avoid.

Beasley (1999:53), "Liberal feminism follows the line of thinking in specifically asserting that women are not fundamentally different to men and yet are denied opportunities on the basis of their sex." Every human have opportunities in all aspect because women have rights too.

Schwartzman (1969: 1) :

"From the time of the women's suffrage movement to the more recent battles over abortion, women have formulated their demands in terms of equality, autonomy, and individual rights.... Liberal concepts can work to undermine women's interests, reinforcing not only sexism, but also racism, classism, and other forms of oppression."

It means that liberal feminism can decrease women's about racism, classism, and any oppression options. 
Tong (2009 : 34), "Liberal feminists wish to free women from oppressive gender roles-that is, from those roles used as excuses or justifications for giving women a lesser place, or no place at all, in the academy, the forum, and the marketplace." It means that liberal feminist can give a space for women get academy, can speak up in the forum, and also in marketplace.

According to three statements above liberal feminism can give women freedom to do everythings that women's want without racism, classism, and many oppression.

Definition of liberal feminism itself is viewpoint to putting women who have full freedom and individual. This movement state freedom and equality based on rasionality dan divide between private and public. Every human have capability to think and act rasionality, especially in women, the roots of oppression and backwardness for women because of women's fault herself. Women must prepare herself in order to compete and get equality with men in public.

Women emancipations have existed to erase different of gender. Feminism is a ideology which use to break out patriarchy, search for the root or causes of discrimination of women and also look for the solutions. In other words, feminism is a theory for women liberation.

Ideology of liberal feminism is equality in every chance and desire in order to every individual (men and women) have given freedom to choose what goodness the way she or he did without harm others. The prior purpose are make the society feel equitable and care of freedom places to make an improvement. Only from those environments, women and men can develop their self. General view of the liberal feminists is that suppress of women is caused by social and legal barriers that block their access to public sphere of politics and economics. Liberal feminists demand that liberals follow their own principles of universal human rights and equality and demand equal treatment of women and men, insisting that women are fundamentally similar to men. These theorists argue for law to be gender blind- that there should be no restrictions or special assistance on the grounds of gender.

Emphasizing equal individual rights and liberties for women and men, downplaying sexual differences. Liberal feminism is the most widely accepted social and political philosophy among feminists. Liberal feminists defend the equal rationality of the sexes and emphasize the importance of structuring social, familial, and sexual roles in ways that promote women's autonomous self-fulfillment. They emphasize the similarities between men and women rather than the average differences between them, attribute most of the personality and character differences between th sexes to the social construction of gender, and tend to promote a single set of androgynous virtues for both women and men.

So, feminism liberal is one of branch feminism which is presented of equal rights for women can be accepted legally and also get improvement in social aspect in order to every women rights can be realization if women can be equal with men.

Beasley (1999:51), “[Liberal Feminism] is women's position in society is seen in terms of unequal rights or 'artificial' barriers to women's participation in the public world, beyond the family and household." It means positions of women in that moments, there are many unequal rights beyond women and men. Discrimination always happen and it could not avoid.

Beasley (1999:53), "Liberal feminism follows the line of thinking in specifically asserting that women are not fundamentally different to men and yet are denied opportunities on the basis of their sex." Every human have opportunities in all aspect because women have rights too.

\section{Schwartzman (1969: 1) :}

"From the time of the women's suffrage movement to the more recent battles over abortion, women have formulated their demands in terms of equality, autonomy, and individual rights.... Liberal concepts can work to undermine women's interests, reinforcing not only sexism, but also racism, classism, and other forms of oppression."

It means that liberal feminism can decrease women's about racism, classism, and any oppression options.

Tong (2009 : 34), "Liberal feminists wish to free women from oppressive gender roles-that is, from those roles used as excuses or justifications for giving women a lesser place, or no place at all, in the academy, the forum, and the marketplace." It means that liberal feminist can give a space for women get academy, can speak up in the forum, and also in marketplace.

According to three statements above liberal feminism can give women freedom to do everythings that women's want without racism, classism, and many oppression. Definition of liberal feminism itself is viewpoint to putting women who have full freedom and individual. This movement state freedom and equality based on 
rasionality dan divide between private and public. Every human have capability to think and act rasionality, especially in women, the roots of oppression and backwardness for women because of women's fault herself. Women must prepare herself in order to compete and get equality with men in public.

\section{RESEARCH FINDING AND ANALYSIS}

This research uses descriptive qualitative method; data analysis is described by using words. The procedure data is collecting from watching the movie over. Then understood and analyzed content of story. Source data is taken from the film based on real events in North Country Movie. The problem of this research focus on liberal feminism of main character to get her equal rights in workplace. The material is about discrimination and sexual harassment in workplace especially for women. This research approximately takes two months to be done with analysis which are limeted because the data can be found in big library or credible online resources and all of those books are old. The instruments of this paper are movies, books, document from library or online resources to finish this research.

\section{RESULT AND DISCUSSION}

The writer is interested to analyze liberal feminism of main character in North Country movie. She is a bravely women because she can claim the company to make fair rules for women who works in mine. In this case the writer only analyze the reason and impact of main character fight her equal right then obstacles that she have to faced it.

Liberal feminism in North Country movie is related one factor. The factor is Josey's life. From the first, Josey is a beautiful girl that all man have interested with her. It all changed, when she got pregnant because of raped by her teacher. After that she met her husband, but she is unhappy living with him so she escaped. To continue her life, she decided to work in mine company. Then, she got some trouble there such as discriminations and sexual harassment because most of employee are men.

\section{Reason for Equal Rights.}

This movie tells about women who has no freedom in workplace in 1989. The main character in this movie shown as women who have problem because of all women in her workplace, Mine, there are many problems because of their sex. The writer finds a theory about liberal feminism which is related with this movie.
Beasley (1999:51), “[Liberal Feminism] is women's position in society is seen in terms of unequal rights or 'artificial' barriers to women's participation in the public world, beyond the family and household." The writer analyzes about Josey Aimes as the main character here and compare the dialogue from the movie with theory about liberal feminism. The writer analyzes reason fight equal rights because every tragedy or accident which appears in this movie are discrimination and sexual harassement.

\section{A. Discrimination of Sex Aspect}

It is one of main point which happend in this movie. It can be seen when the main character Josey Aimes fight for women's rights in mine company. In workplace, there are many discriminations happened from high position (president, vice president, manager, leader group) until lower position (employee, labour, security, office boy). Dicriminations is an action who do different treatment to certain individual. It usually happens in society, because human preference discriminate someone. When somebody in unfair treatment because of different sex, gender, ethnic, race. Josey and the other women in mine, got discriminations such as directly said about sex.

a. Arlen's Statement.

Those discrimination has happened on many places such as at women's room, mine outside, and also Arlen's room. In this movie the main character Josey Aimes is a bravely woman, but until she decided to work at mine as Glory's opinion all changed. Josey was getting discriminations there and she can not do anything because it rules.

Craig (2007 : 26), “discrimination for most people may be "a showing of prejudice in treatment", this definition is clearly out of step with the development of the concept of discrimination"

Women in the mine who have fulfill the requirements of being employee must have breafing first from Manager to know the area around Mine. All women in this scene, they get on together in a room to hear the instructions from Manager, Arlen, about how to work in mine. All women's there are hearing what he said seriously.

Arlen :"The mine is a shit pit. Dirt everywhere.Loud as all get-out. You'll be hauling, lifting, driving and all sorts of other things a woman shouldn't be doing. If you ask me but Supreme. Court didn't ask me, did they ?"

(Duration : 00:17:00 - 00:17:55) 
From the bold dialogue above, the writer thought the theory and what shown in the movie has a relation. It shows that women in those places should not in there because it was so unappropiate for women and if she still wants to work there she must receive the conditions like that. After that Arlen go out room to prepare the tour of mine. All women in the room feel strange about what Arlen said at that time. She think that Arlen is a Homo who are not interested with women.

\section{b. Passiveness of Man Co-Worker}

In other places at mine outside, Glory, friends of Josey, would like to take a break after she feels tired driving the truck. Then she call her friends Hanks, father of Josey, to take a break then continued again. But in Hank's mind, they had taken a break a moment ago so he does not need to take a break. After debate too much, Glory gives up and continue do what Hank's will.

Epstein (1970 : 40) stated "Many critics of the push for women's participation in occupations and professions claim that although women's treatment reflects their obvious differences, they are honored equally with men in the society."

\footnotetext{
Glory : "Hank, I need a five-minute break."

Hank : "You took a coffee break an hour ago."

Glory : "That's the point, Hank. She's been drinking coffee like everyone else."

Hank : "Hey, Glory, are you talking as a union rep or just butting into anybody's business as usual ?"

Glory : "All I'm saying is that you can whip it out anytime, Hank. We gotta pull the coveralls all the way down, you know I'm saying ? We start peeing in our seats. I don't think the next shift's gonna be too happy about it."

Hank : "You got another load to get. So pull them up and go get it."
}

(Duration : 00:19:51 - 00:20:47)

After doing her job Glory with male co-workers, they were discussing her problems in mining. In the middle of conversation and jokes by her colleagues, she submit several problems that faced by women workers there but the response she obtained is simply a joke that has implicit meaning and being ignorance.

\footnotetext{
Men : “Okay, there's nothing else, I move to adjourn."

Glory : "There's one more thing."

Men : "What's that?"

Glory : "Porta-Johns."
}

$\begin{array}{ll}\text { Men } & \text { : "Here we go again." } \\ \text { Glory } & \text { : "I got one girl with a bladder infection } \\ & \text { from holding it in all day. Maybe Pete } \\ \text { over there likes sitting in his own pee. } & \\ & \text { But I don't. Like it or not, represent } \\ \text { members of this union who just happen } \\ \text { to be female." }\end{array}$

Men :"All right. Well, if we do get management to give you girls PortaJohns what are you gonna do for us?"

Glory : "Didn't you hear, Pete ? Discount blowjobs, for everybody but you."

(Duration : 00:24:59 - 00:25:34)

From the explanation above the writer found the similarities between the theory and what shown in movie. It shown that Glory only wanted her male co-worker aware of his actions who always peeing on the bench wheel when they drive mining trucks. Their behavior are dirty, it should be taken seriously so her co-worker would not feel aggrieved that their behavior are dirty. When women working in a place which is the majority of men always being like that, men do not always clean and tidy in terms of taking care of themselves. Although every aspect has different aspect, but take care of each other is important to make all related and has equal rights.

\section{c. Josey’s Complainment}

There is a part when Josey and Sherry at the time was cleaning the Powder Room of the mines, they meet with other her men co-worker; they all are Boby's group, one of old friend Josey. Firstly they were just joking around but suddenly they do harassment to Sherry who against their behaviour, Josey see it then reported the incident to Arlen, her manager. But Josey's report is not considered and only used as a regular thing that often happens and is common.

Tomasevski from Universal Declaration of Human Rights, 1948 (1993:45) stated that "Everyone is entitled to all the rights and freedoms... without distinction of any kind, such as race, colour, sex.."

Having rights and freedoms means thinking of do whatever she want, give opinion or critical for all, and also take in special places in some places without thinking about race, colour or even sex.

Arlen : "Do you even know what's going on out there?"

Josey : "Yeah."

Arlen : "Sweetheart, this country's elected a president who's letting the world flood our market with cheap steel. We're knee-deep in lay offs. Mines are closing left and right." 
Josey : "What's this got to do with Earl laying hands on Sherry like that?"

Arlen : "Hooh.. Are you hearing a word of what I'm saying ? You're taking jobs where there aren't any to take. The boys aren't your friends. I'm not your friend. You got no business being here and you damn well know it. But you're not hearing that, are you ? so let's try something new. How about work hard, keep your mouth shut and take it like a man."

Josey : “All right. Maybe I'll go see Mr. Pearson. He said come to him if I had a problem."

Arlen : "No, You don't see Pearson. I see Pearson. You know ? when you've got a real problem, take it up with me and I'll be happy to help. All right ?"

(Duration : 00:29:36 - 00:30:36)

Based on naration above the writer thought the theory and action in movie are related each other. It shows when Josey felt discrimination that occurs between male employees and female employees. Women's rights are not respected at all both in terms of treatment and in the opinion expressed in the mining company. As if the opinion of its female workers is childish. "Do it like a man" that is what was on women's workers mind according to Arlen. When Josey feels the report is not addressed properly, it will reported that matter to his superiors that much higher, Mr. Pearson, the director of the mining company. Arlen suddenly wondered why Josey knows its director, and then he quickly said things are ready to assist any Josey and the report will be processed immediately.

\section{B. Sexual Harassement of Sex Aspect.}

Sexual harassement aspect also become a cause that make women must get equal rights in workplace. Believe or not, many sexual harassement happend in all over the world and this movie is only representation the real case in Minesota, Mexico. Sexual harassment in workplace can be defined as a deviant behaviour committed by certain people and was not expected by the affected victims of sexual abuse herself. Josey and other women co-worker as victims of sexual harassement in mine that all workers there majority are men.

\section{Healty All Body Check}

In mine company, before they hire an employer, it usually there are many test such as written, interview, and healty test. All employees has to pass through all the test especially healty test although the person are men or women. Josey has to pass it when she decided being mine employee. She feel uncomfortable do healty test by a man doctor which is means that he can see all her body from top into bottom. It is a shame for her, but she like or not she must accept it. But in one side, this is one of forms of sexual harassement.

Boland (2005 : xv), "Sexual harassment is a type of sexual discrimination in the workplace. It includes unwelcome sexual advances, requests for sexual favors, and sexual conduct that is directed toward a person because of gender."

Josey knows that was one of risk to work in mine that all her body from top to the buttom have seen by the doctor. Although she tried to explain it but rules is a must.

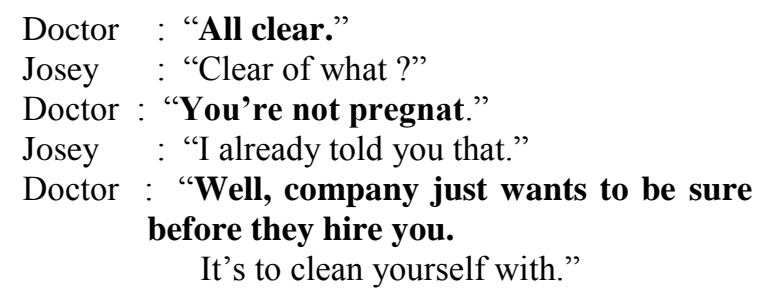
(Duration : 00:12:29 - 00:12:55)

After being accepted as employee in mine Josey directly join in women's group there. She met a lot of women there who has the same experience before and have known about treatment from men. She try to socialization with other to get connected each other. When she enjoy Sherry get something strange in her box lunch there is something unpolite to be there, Penis Joke. But in calm, Josey can reply the treatment with her statement.

Glory : "Come on, let's sit with the girls. Meet the ladies. Ladies, ladies. Josey Aimes."

Big Betty : "Oh, hey. Big Betty. Pleased to meet you."

$\begin{array}{ll}\text { Josey } & \text { : "Nice to meet you." } \\ \text { Peg } & \text { : "There used to be two Betty's" } \\ \text { Glory } & : \text { "Big and Little. Little quit." } \\ \text { Josey } & \text { : "Why ?" } \\ \text { Big Betty } & \text { : "Too little. Hahahaha" } \\ \text { Peg } & : \text { "I'm Peg." } \\ \text { Josey } & : \text { "Hey, nice to meet you." } \\ \text { Peg } & : \text { "Hey, you too." } \\ \text { Josey } & : \text { "Hey" } \\ \text { Sherry } & : \text { "Huys." } \\ \text { Big Betty } & : \text { "How you doing ?" }\end{array}$

Sherry shock that she got her lunchbox with penis joke.

Male : "Hey ! No getting off in the lunchroom, ladies. Hahaaha.."

Peg put down penis on the table while a little bit emotion. 
Josey

: “Well, it won't leave the toilet set up. It won't fart in the bed. I might just marry it."

All the woman are laughing.

Josey : "Right ? You don't mind, do you?"

(Duration : 00:23:46 - 00:24:57)

It was so contempitible used the vulgar joke. Other women there, are usually have experienced before so they see it was intentional doing by men. Josey expressed it as joke but she can handle it.

According to description above the writer thought the theory and what happen to main character in movie shown a relation. It shows in Josey was check her heality by men doctor which is means that he can sees all her body without excuses. It is one sexual harassement and so shameful. Joke penis is also one of vulgar joke that should not to be exist because it contempitible.

\section{Powder Room's Accident}

After all ladies has given the instructions from Arlen in women's room, they got directly tour with Arlen. He gives instructions in the field how to work there by walking around the mine. In one moment, they met Bobby Sharp. $\mathrm{He}$ is one of Josey's boyfriend when senior high. Josey got memories they were together in past, and think that Bobby did not change anything.

Wagne (1992 : 30), "Sexual harassement it must be unwelcome and affect the terms and conditions of employment. As a practical matter, that conduct can include :

- Derogatory or vulgar comments about someone's gender, physical anatomy, or characteristics.

- Sexually suggestive or vulgar language.

- Threats of physical harm.

- Sexually oriented or suggestive pictures, posters, magazine, or other materials.

- Touching someone in a sexually suggestive way, or in a way calculated to invade her personal space.

- Touching of another's breasts, genital areas, or derriere.

In this scene, there are some sexual harassement which happened to Josey and her co-worker.

Arlen : "This down here is taconite. That's what pays bills. We've taken to calling this area the Powder Room. Catchy, don't you think ? Especially since you girls will be the ones cleaning it."

Bobby from the door see it and come closer to all.

Bobby : "So, so, Arlen, which one of these girls is gonna be my bitch ?"

Arlen : "Ladies, meet Bobby Sharp. He runs the Powder Room, where they're short one body."

Bobby : "And we want a nice body. No fatties." Give me the one on the right." (while whispering to Arlen). Go while eyes catching to Josey.

(Durtion : 00:20:48 - 00:21:32)

After that all women there feel strange of Bobby treatment. They all thinks that he use vulgar statement. Bobby was come back to his job and others focus again listen what Arlen said.

In other moments, Josey and Sherry has job to clean the Powder Room. Josey the one who hold the top of water pump, and Sherry holds part of it. Josey see a vulgar picture which draw in the wall and clean it by ejector pump. In other side, Bobby and Earl are near with syringe area. They talk each other about Josey and Sherry and try to flirt her.

Earl : "Nice. She can put her hands on the hose."

Bobby : "Come on, Ladies ! Gotta appreciate the talent." It's a pretty good likeness, I'd say.

Earl : 'Hi, I'm Earl. I don't think we've met yet. How about a cigaratte, then ?"

Sherry : "Go fuck yourself."

Earl : "Oh, be nice now, darling. Come on, how about the smoke?"

Sherry wants take cigaratte from her pocket, but suddenly Earl wants to take by himself while he touchs her breast.

Earl

Josey

Ricky

Earl

: “No, it's ok. I'll get it myself"

: "Come on, Earl"

: “All right, fun's over."

: "Just trying to see if she's got a full pack. She don't. You're okay. All right, back to work, slacker, come on.

$\begin{array}{ll}\text { Sherry } & \text { : "Boy Scout" } \\ \text { Josey } & \text { : "You okay?" } \\ \text { Sherry } & \text { : "Yeah" }\end{array}$

(Duration : 00:28:38 - 00:29:35)

From description above, dialogue and theory are related. It shows in that century, there are so many sexual harrasement which happened to women and being object of sexual harassement forms that the writer see in this scene are when Boby said "bitch". Bitch is lower rank nickname for women in society. 
It is not polite to call women like that. Giving unpolite statement is prohibited moreover until touching sensitive area it has became a problem.

After analyze the description above, the writer gets conclusion that in this movie liberal feminism did not exist because of discrimination and sexual harassement which happened in women there. Those situation always continued until there is somebody can stop it.

\section{Impacts on Equal Rights.}

Josey still believes that she can get her equal rights and also other co- worker women in mine. Since she has seen many tragedy there such as discrimination and sexual harassement which are women being object.

Beasley (1999:53), "Liberal feminism follows the line of thinking in specifically asserting that women are not fundamentally different to men and yet are denied opportunities on the basis of their sex."

Every behaviour has impacts which is right or wrong. There are causes and effect. Here are the character who gets impact from equal rights, such as :

\section{A. Sherry}

Sherry is one of the workers who simply gorgeous woman who has a beautiful body. Sometimes she is often a "game" by other male workers. often times he experienced something unpleasant things from co-workers their male counterparts. When all the workers are working in mine, Sherry met with 3 male workers who always tease her and play the games. Sherry casually denied that anything said by the male workers.

Men I : "Sherry, sherry, quite contrary. Kiss my ass, it's really hairy."

Sherry : "Oh, a real funny guy. "

Men II : "What are you doing in the pit?"

Men I : "Filling in for Glory while she's out. Just in time to use the new Porta- Jane?"

Men II : "You don't mind, we took a big dump in that this morning."

Sherry : "Oh, how charming."

Sherry come in to the toilets and the theree men her co-worker are laughing her.

Men I \& II: "Sherry"

The Porta-Jane has shaken by the men.

Sherry : "Hey, cut it out! Stop it! Cut it out !"

Ricky : "What the hell's going on?"

Men III : "They got Sherry in the crapper"

Sherry : "Stop it, guys! Cut it out, It's not funny!"

Men III : "Somebody's gonna get hurt."

Sherry : "Knock it off!"
Ricky : "Let her out! That's enough."

Men I : "Turn this fucker over!"

(Duration : 00:59:36 - 1:00:55)

From dialogue above proves that the third of the male co-workers were doing something inhuman, when Sherry went into portable toilets suddenly they wiggle the toilet so sherry feel frightened there, but they only laugh at her. The others co-worker saw that accident and tried to stop them immediately. However, they still continues to wiggle the toilet until they fall it to the ground which causes Sherry soaked with feces. Sherry feels this treatment is on of insult for her and she only weep.

\section{B. Josey}

Sherry accident has become one of reasons that there is must be equal positions for women and men. Sherry has become an object of men "games" in mine. Josey would like to complaint to her boss directly, Mr. Pearson. She has proof that all women is being treated in unusual and always getting discriminations. So she decide to complaint and go to centre of company office.

Ms. Pearson : "Send her in, Please."

"Ms. Aimes, sorry to keep you waiting so long. Please sit."

Josey : "Gentlemen"

Ms. Pearson : "I asked some of my colleagues to sit in, if you don't mind."

Josey : "No"

Ms. Pearson :"I believe you know Mr. Pavich?"

Josey : "Yes, I do. Mr. Pavich was the one who told me I had to take a day off work to come and see you."

Arlen : "I didn't want to waste your time, sir."

Mr. Pearson : :Well, I appreciate that. But it's not a waste at all. Ms. Aimes has a problem, and we're gonna solve it."

Josey : "Thank you, Mr. Pearson. That's... That's really great. I didn't want to forget anything, so I wrote a couple of things down on a piece of paper here."

Mr. Pearson :"Excuse me, Josey.. Do you mind if I call you Josey?"

Josey : "No"

Mr. Pearson : :I'd like to make this easier for you if you don't mind. I already know what you're going to tell me. I've been well-briefed. “” 
Josey

Mr. Pearson

: "That's great. I just thought that a few of these.."

Josey

Mr. Pearson

:"Please, I think you'll be pleasantly suprised."

: "Okay"

:"Well, the current union contract requires that an employee provide us with two week's notice before leaving his position. However, given how obviously emotional this has been for you we're willing to do something special in this case. We've decided to waive the twoweek requirement and allow you to tender your resignation effective immediately."

Josey : "No. I'm sorry. I'm not resigning. "

Mr. Pearson : "Mr. Pavich will take care of the details."

Arlen

Josey

Mr. Pearson

: "Be happy to."

: "No. I'm not quitting. I need this job. "

"Well, then I suggest you spend less time stirring up your female co-workers and less time in the beds of your married male co-workers and more time trying to find ways to improve your job performance. Does anyone else have anything to add ?"

Arlen

Mr. Pearson

: "That says it."

"Josey, thank you again for making the drive down here. Now, if you don't mind we have other business. "

(Duration : 1:02:00 - 1:04:35)

The conversation above is the conversation in meeting room between Josey and all high group member include Mr. Pearson as Director. This situation is one of impacts of discrimination and sexual harassement that happens to all women coworker. When Josey comes to the rooms with smile, because she can report what she and other women co-worker got bad treatment and discriminations there. But when she want to tell the accident, her bos have make strategies that she will be reputed to resign by herself and also threatening quit of job immediately. Josey feels more uncomfortable there, and being threated by all man there. There are Mr. Pearson, Arlen, and two his colleagues. She do not have rights to express her complaint to the company in fact her opinion they did not want to hear.

In women's room, there is tragedy happened. After she met with Mr. Pearson to complaint what happen in mine, she is being a target now. All her co- worker dislike her because of her behaviour. Josey is a bravely women who fights for equal rights in workplace but not all people can accepted it.

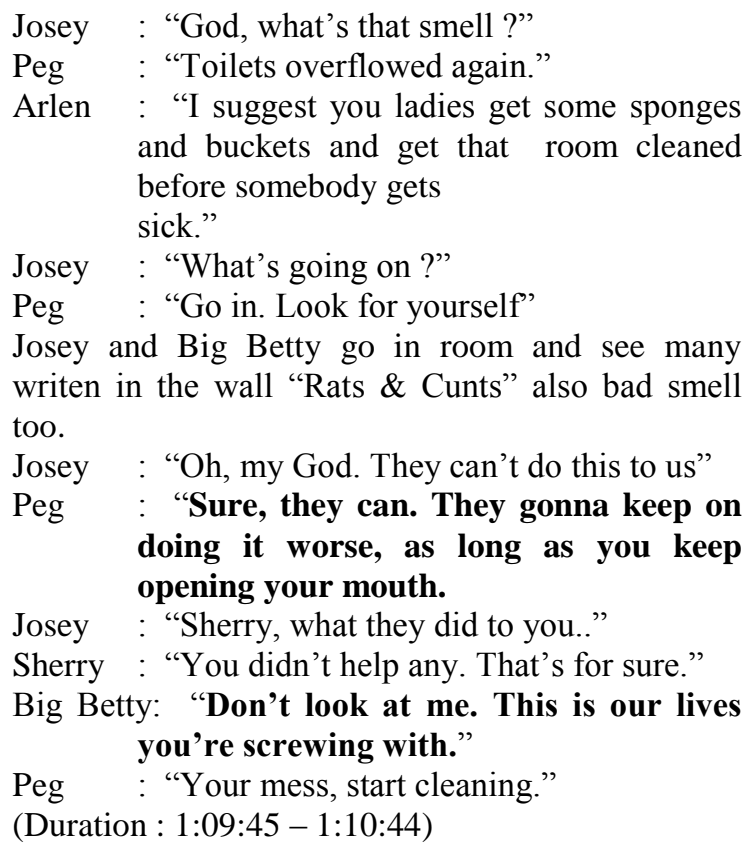
and buckets and get that room cleaned before somebody gets writen in the wall "Rats \& Cunts" also bad smell too.

Josey : "Oh, my God. They can't do this to us"

Peg : "Sure, they can. They gonna keep on doing it worse, as long as you keep opening your mouth.

Josey : "Sherry, what they did to you.."

Sherry : "You didn't help any. That's for sure."

Big Betty: "Don't look at me. This is our lives you're screwing with."

Peg : "Your mess, start cleaning."

(Duration : 1:09:45 - 1:10:44)

Josey feels there is nobody can help her. Actually, she did it for her women co-worker but they did not reliazed it and afraid to loose the job. After that in workplace, she met Bobby call her to Powder Room. Suddenly, he lay a hand on her and try to threaten to her.

Bobby : "You're one crazy bitch, you know that?"

Josey : "You said you had a job for me."

Bobby : "Yeah, You like that, don't you ? You like that. To grab your pussy like that, don't you ? Forgot you liket it a little rough. You're gonna learn the goddamn rules if I have to beat them into you myself. Damn you, Josey."

(Duration : 1:11:29-1:12:12)

Those descriptive above proves that there are many intimidations which happens to Josey. Knowing that she unappreciated anymore in workplace, she decided to sue the mine and try to finish the case in court. Then she asked a help of Glory's friend, Bill White. She needs all women co-worker to support her but no one can support her. After analyze the descriptive above, the writer gets conclusion that being liberal feminist is not easy enough because there are many effect or impact that must faced Josey as main character. Liberal feminism want that everything has equal and although women and man have the equal rights too. Impacts for main character in movie was so hard to describe because 
she must strong inside before she faced it more than this.

\section{Obstacles Faced for Fights Equal Rights.}

Josey try to sue the mine, and hope that the company will appreciated their employee then giving especiality in some rules. When she continue it in court, she needs everyone to stand up for her who has the same experience like her. They all thinks that she is crazy. At first, she try to discussed with Glory, but she think that she is crazy and did not be grateful can be alive like that, but in Josey's mind it must take an action because if she allow this problem away, it will be never end. After that, Josey struggle to invite Sherry but she do not want because she do not want to come back again to mine. She is one of victims who got discrimination and sexual harassement like Josey but she refused it. She is never give up and keep try in sue mine with strong conviction in her heart.

In one moment on Affiliated Steel Workers Local 820 Proud Confession, she try to invite all women and her co-worker to stand for her in those chance. But only intimidations she get in the rooms, and everybody in that rooms hate her.

$\begin{array}{ll}\text { Men } & \begin{array}{l}\text { :"Get your ass home! I asked if } \\ \text { any brothers would like to speak." } \\ \text { :"Bylaws say no meeting can } \\ \text { adjourn if a member wants to }\end{array} \\ \text { Speak his or her mind." } \\ \text { Men } \\ \text { :"I got your gavel right here, } \\ \text { bitch!" } \\ \text { :"I am s.. I am still a member of } \\ \text { this union." }\end{array}$

(Duration : 1:31:50 - 1:32:25)

She keep her step into the stage although everybody did not want to see her. But once again she try to convince all member that she is right and only want get equal rights not discrimination or sexual harassement. In men side, they are only laughing when Josey expressed her opinion and in women side only keep silent and giving stare at her in pity. Her father, Hanks, is trying to support her and give his statement in order to Josey can speak up. She is so nervous and afraid if there are some protests but she must do it.

\footnotetext{
Men : "Can't hear you. I can't hear you."

Josey : "My father never wanted me to work here."

Men : "That's right. Sit on this and talk."

Josey :"Pretty much stopped talking to me because of it. I know some of you here think I wanna shut down the mine."

Men :"Don't worry, sweetheart, we won't let it happen!"
}

Josey : "I don't wanna shut down the mine. I just wanna go to work like everyone else. Get paid end of the week, feed my kids, and hell maybe now and then have enough for a beer at Tee-Gees Saturday Night. And not a woman in that back row don't know what I'm talking about. You all know what's been done."

Moderator : "Time's up!"

Josey :"We need these jobs. And it's not gonna stop until we say stop!"

(Duration : 1:33:15 - 1:34:08)

Josey feels frustated when in the court no one stand for her and she got other obstacles again, its about explanation of her last memories that she has been raped by her teacher and Boby has false confession. It so shameful for her and also her family.

Conlin : "Who is Sammy's father ?"

Josey : "I don't know who Sammy's father is."

Conlin : "Is that because you've had so many sexual partners?"

White : “Objection. Plaintiff's sexual history is irrelevant. Your Honor."

Judge : "Overruled. Ms. Conlin who is the gentlemen entering the courtroom ?"

Josey's teacher come in to the court.

Conlin : "Mr. Paul Lattavansky, Your honor, Ms. Aimes's high school teacher. We've subpoenaed him as an impeachment witness."

White : "I have so many objections, I don't know where to start."

Judge : "Witness will answer."

Conlin : "Again, Ms. Aimes who is Sammy's father?"

Josey : "My son has got nothing to do with any of this."

Conlin : "Is it true that you and your teacher Mr. Lattavansky had a sexual relationship at one time?"

Josey : "A "relationship" ? What the hell you been telling them, Bobby?"

Conlin : "Ms. Aimes, did not, at the age of 16, engage in a sexual relationship with your high school teacher?"

Josey reminds that some long memories ago about she was raped by her teacher.

Conlin : "Are there any other witness to this alleged rape ? anybody besides Mr. Sharp that can corroborate your testimony ?"

Josey : "No."

(Duration : 1: 38:49 - 1:43:09)

From story above Josey got frustated because her raped case involved her sue. Since Bobby testimony about it and finally it became discussed. She tries to answer the questions from Conlin as she 
could do. For the first she pretend that she do not know who Sammy's father, but when Conlin bring her senior high teacher, Mr. Paul Lattavansky she is very shock because she met him in court after long time never see him again. She is very hate him but she did not hate Sammy, her child.

\section{CONCLUSION}

North Country movie has some factor of liberal feminism, such as discrimination and sexual harassement aspects especially about sex. The writer is more focus on the main character, Josey Aimes, because she was a bravely women then try to sue the mine in order to get equal rights for women co-worker there.

As the result of analyzis of North Country movie, the writer get some reason of her fight equal rights and also gets some theories which are can compare with the movie. Many factors that causes the main character fight for equal rights are found through the reasearch. Those reason for discrimination aspects that happen to the main character are women should not work in mine because it is not casual with her gender, different treatment between men and women, then women's opinion ignored. In sexual harassement aspects are vulgar behaviour and statement from men workers, then there are tragedy for ladies at powder room accident. Those reason make the main character bravely to fight for equal rights.

\section{REFERENCE}

Beasly, Chris. 1999. What Is Feminism ? An Introudction to Feminist Theory. London : SAGE Publications, Ltd.

Boland, Mary L. 2005. Sexual Harassement in the Workplace. United States of America : Sphinx ${ }^{\odot}$ Publishing, An Imprint of Sourcebooks, Inc ${ }^{\circledR}$

Butler, Judith. 1990. Gender Trouble. New York : Routledge, Chapman \& Hal, Inc.

Craig, Ronald. 2007. Systemic Discrimination in Employment and the Promotion of Ethic Equality. Netherlands : Martinus Niijhoff Publishers.

Epstein, Cynthia Fuchs. 1970. Women's Place Options And Limits in Professional Careers. London : University of California Press, Ltd.
Friedman, Lauri S. 2009. Writing the Critical Essay Discrimination. United States of America : Greenhaven Press.

Gibson and Johnson. 1998. Sexual Harassment Prevention Training Manual For Managers and Supervisors How to Prevent and Resolve Sexual Harassement Complaints in the Workplace. United States of America : CCH INCORPORATED

Hook, Bell. 2000. Feminism Is For Everybody : Passionate Politics. Canada : South End Press.

Jaggar, Ellen J. 1983. Feminist Politics and Human Nature. Great Britain : The Harvester Press Limited.

Marshment and Gamman. 2010. Tatapan Perempuan : Perempuan Sebagai Penonton Budaya Populer. Yogyakarta : Jalasutra.

Martin, David. 2006. A Specially Commissioned Report Discrimination Law And Employment Issues Avoiding the Pitfalls in : Age, Disability, Gender, Race, Religion, Sex and Sexual Orientation. London: Thorogood Publishing, Ltd.

Schwartzman, Lisa H, . 1969. Challenging Liberalism : Feminism As Political Critique. United States of America : The Pennsylvania State University Press.

Tomasevski, Katarina. 1993. Women and Human Rights. London : Zed Books, Ltd.

Tong, Rosemarie. 2009. Feminist Thought : A More Comprehensive Introduction Third Edition. Colorado : Westview Press.

Wagner, Ellen J. 1992. Sexual Harassement in the Workplace : How to Prevent, Investigate, and Resolve Problems in Your Organization. United States of America : Creative Solutions, Inc.

Williams and Delliger. 2010. Gender and Sexuality in the Workplace. United Kingdom : Emerald Group Publishing Limited.

\section{PROFIL PENULIS}

Dwi Puji Hastuti, S.S lahir di Jakarta. Bergabung dengan Akademi Bahasa Asing sejak 2015. Telah mendapatkan gelar Sarjana Sastra di Sekolah Tinggi Ilmu Bahasa Asing dengan program studi sastra 
inggris dan saat ini sedang melanjutkan studi S2 di Universitas Indraprasta PGRI Jakarta. Beberapa artikel yang telah diterbitkan juga diseminarkan diantaranya: Pengaruh Lingkungan Kerja Dan Disiplin Kerja Terhadap Kinerja Karyawan PT. Intisel Prodaktifakom Jakarta, Sistem Informasi Penjualan Berbasis Web Pada Restoran Caki Cake Karawang.

Deni Gunawan, S.Kom lahir di Karawang. Bergabung dengan Akademi Manajemen Informatika sejak 2016. Telah mendapatkan gelar Sarjana Komputer di Sekolah Tinggi Ilmu Komputer dengan program studi sistem informasi dan saat ini sedang melanjutkan studi S2 di STIMIK Nusa Mandiri Jakarta. Beberapa artikel yang telah diterbitkan juga diseminarkan diantaranya: Pengaruh Lingkungan Kerja Dan Disiplin Kerja Terhadap Kinerja Karyawan PT. Intisel Prodaktifakom Jakarta, Sistem Informasi Penjualan Berbasis Web Pada Restoran Caki Cake Karawang.

Ria Andriani, S.M lahir di Padang. Bergabung dengan Akademi Sekertari dan Manajemen sejak 2015. Telah mendapatkan gelar Sarjana Manajemen di Institut Bisnis dan Informatika Kosgoro dengan program studi manajemen dan saat ini sedang melanjutkan studi S2 di Universitas Budi Luhur Jakarta. Beberapa artikel yang telah diterbitkan juga diseminarkan diantaranya: Pengaruh Lingkungan Kerja Dan Disiplin Kerja Terhadap Kinerja Karyawan PT. Intisel Prodaktifakom Jakarta, Sistem Informasi Penjualan Berbasis Web Pada Restoran Caki Cake Karawang. 